ADDIN, Vol. 10, No. 1, Februari 2016

\title{
RADIKALISME ISLAM DALAM PERSPEKTIF EPISTEMOLOGI
}

\author{
Fathul Mufid \\ STAIN Kudus, Jawa Tengah, Indonesia \\ fathulmufid2013@gmail.com
}

\section{Abstrak}

Gerakan radikalisme Islam, terutama di kawasan Timur Tengah yang mayoritas berpenduduk muslim, menyebabkan terjadinya image negatif terhadap Islam yang selama ini dipromosiken sebagai agama cinta damai dan toleran. Fenomena yang buruk tersebut jelas bukan mencerminkan ajaran Islam yang sebenarnya, karena hakikat ajaran Islam adalah membawa rahmat bagi selurub alam semesta. Tulisan ini merupakan hasil penelitian literer penulis yang terkait dengan epistemologi kaum radikalisme muslim dari berbagai aliran yang memiliki kesamaan sudut pandang dalam memahami ajaran Islam. Model epistemologi kaum radikalis muslim dalam memahami ajaran Islam tersebut ternyata sangat memengarubi perilaku kebaragamaannya dalam kehidupan sosialyang berujung pada sikap eksklusif, radikal, dan ofensif, baik kepada sesama muslim yang berbeda pandangan maupun kepada nonmuslim. Penelitian ini bertujuan untuk menguak keunikan epistemologi kaum radikalisme muslim di dalam memahami al-Qur'an dan hadis, sehingga mengubah wajah Islam yang hakiki (raḥmatan li al-'alamin) menjadi wajah yang seram, sangar, dan menakutkan. Pendekatan hermeneutika digunakan penulis dalam menganalisis data-data dokumenter yang dikumpulkan untuk dapat mengungkap latar belakang historis, sosiologis, ataupun filosofis epistemologi kaum radikalisme muslim. Temuan penelitian ini adalah bahwa kaum radikalisme muslim hanya berpegang pada alQur'an dan hadisyang dipahami secara literal, harfiah, dan skriptural, sehingga melabirkan pemahaman, fanatik, ekesklusif, dan bitam-putih. 
Fathul Mufid

Kata Kunci: Radikalisme, Epistemologi, Islam, Literal, dan Fundamentalisme.

\section{Abstract}

ISLAMIC RADICALISM IN THE PERSPECTIVE OF EPISTEMOLOGY: The movement of Islamic radicalism, especially in the Middle East region that the majority of the population is Muslim, led to a negative image against Islam that was promoted as a peace-loving and tolerant religion. The bad phenomenon is certainly not reflective of the actual of Islamic teachings, because the essence of Islam is bringing the grace for the whole universe. This paper is the result of the author's literary research related to epistemology of Muslim radicalism from various schools that have the same point of view in understanding the teachings of Islam. The epistemology model of radical Muslim in understanding the Islamic teachings apparently has a strong influence to the religiosity behavior in social life which culminate in exclusive, radical, and offensive attitude, both to fellow Muslims of different views as well as to non-Muslims. This study aims to reveal the uniqueness of the epistemology of Muslim radicalism community in understanding the Qur'an and Hadith, thus changing the face of essential Islam (rah. matan li al-alamin) into a spooky and scary face. The author used hermeneutics approach in analyzing the documentary data which were collected for revealing the historical, sociological or philosophical epistemology background of radical Muslim community. The findings of this research is that the radical Muslim community just hold on Qur'an and Hadith that is understood literally, word to word, and scripturally, thus giving birth to the understanding, fanatical, exclusive, and blackand-white.

Keywords: Radicalism, Epistemology, Islam, Literal, and Fundamentalism.

\section{A. Pendahuluan}

Terjadinya konflik bersenjata antar umat Islam yang berbeda paham atau aliran dan kekerasan yang dilakukan sebagian kelompok radikalisme muslim kepada pemeluk agama lain ternyata telah menimbulkan banyak kerusakan dan kehancuran, baik jiwa maupun harta benda, serta menghancurkan sendi-sendi 
kehidupan bangsa-bangsa di Timur Tengah khususnya dan umat manusia pada umumnya. Fenomena yang buruk di beberapa kawasan tersebut jelas bukan mencerminkan ajaran Islam yang sebenarnya, karena hakikat ajaran Islam adalah rahmatan li al'́alamin. Akan tetapi, faktor politik, ekonomi, budaya, militer, baik regional maupun globallah yang menyebabkan terjadinya konflik berdarah dan merusak nilai-nilai kemanusiaan, keadilan, dan keadaban tersebut.

Islam sebagai suatu agama sudah barang tentu memiliki ajaran yang bersifat universal dan komprehensif, mengandung unsur-unsur ajaran yang kompleks, di mana pada bagian tertentu terdapat prinsip-prinsip ajaran yang bersifat eksklusif (akidah) dan pada bagian-bagian lainnya (hubungan sosial) bersifatinklusif. Ekslusivisme yang dimaksud di sini adalah suatu pandangan dalam Islam yang meyakini keunggulan dari kebenaran ajaran Islam, sekaligus menegasikan ajaran agama lainnya, sehingga tentu saja ada kecenderungan tindakan dan keyakinan yang berbeda ketika tampil dalam masyarakat plural. Dalam rangka membangun kerukunan hidup dalam masyarakat yang pluralis, terutama dari aspek agama, maka kegiatan dialog lintas agama mengenai dimensi-dimensi eksklusivitas dan inklusivisitas amat diperlukan. Melalui dialog ini, umat dari masing-masing agama bisa saling mengenal dimensi-dimensi eksklusivitas agama selain dari agama yang dianutnya. Dengan duduk bersama ini diharapkan adanya perubahan pandangan dan sikap terbuka para penganut agama yang berbeda, yakni semakin saling menghargai perbedaan dan bersikap toleran terhadap dimensi-dimensi eksklusivitas dalam ajaran agama pihak lain, serta tidak menimbulkan sikap fanatismenegatif yang mengarah pada tindakan radikal.

Diskursus radikalisme dalam Islam yang akhir-akhir ini menarik semua pihak memiliki keterkaitan yang spesifik dengan gerakan fundamentalisme di dunia Islam. Fundamentalisme dalam Islam merupakan gerakan yang menentang westernisasi dan ditampilkan sebagai gerakan alternatif system of life bagi masyarakat muslim. Ekstremitas kaum fundamentalis secara internal disebabkan oleh beberapa faktor, antara lain kecenderungan memahami nash secara literal, perhatian yang 
berlebihan pada masalah furüiyah, minimnya wawasan tentang hakikat Islam, dan lemahnya wacana keilmuan sejarah dalam kehidupan sosial. Secara eksternal, fundamentalisme muncul di dunia Islam disebabkan oleh beberapa faktor pula, antara lain imperialisme, westernisasi, Kristenisasi, sistem pemerintahan, kesenjangan ekonomi, sekularisme, liberalisme, dan terutama sikap Barat yang tidak adil dalam konflik di Timur Tengah, terutama antara Palestina dan Israel. ${ }^{1}$

Ajaran Islam dapat dipahami dalam konteks hubungan manusia dengan Tuhannya (ḅablun min Allah) ataupun hubungan antar sesama manusia (hablun min an-nās). Ajaran Islam yang bersifat eksklusif terutama terdapat pada ajaran yang berbasis teologis (tauhid) dan ubudiyah, yakni berkaitan dengan $\underline{b}$ ablun min AlTah. Adapun ajaran dalam hubungan antar sesama manusia (mu'amalah), eksklusivitas hanya ditemukan secara terbatas pada beberapa hal saja. Islam menganjurkan umatnya untuk membangun kerja sama yang harmonis dan saling menguntungkan, dan sama sekali tidak berakibat pada semakin meluasnya kezaliman, kenistaan, dan kemaksiatan. Sebagai bagian yang tak terpisahkan dari kehidupan sistem sosio-religius yang pluralistis, maka umat Islam diharapkan lebih cerdas dalam memahami dan mengamalkan ajaran agamanya. Ajaran-ajaran yang bersifat inklusif hendaknya ditumbuh-suburkan dalam berbagai sektor kehidupan sosial, ekonomi, dan politik dengan cara-cara yang bijaksana, sehingga dapat membuahkan keamanan dan kenyamanan, serta kemakmuran hidup bersama.

Fenomena aksi terorisme yang menggunakan kekerasan, seperti penembakan, pengeboman, dan bom bunuh diri yang telah dilakuakan kaum radikalisme muslim adalah dengan menjadikan jihad sebagai alasan pembenaran sekaligus sebagai landasan teologis. Pemahaman jihad dalam epistemologi kaum radikalisme tersebut tidak sesuai dengan makna jihad yang sebenarnya dalam ajaran Islam. Hal ini terjadi karena adanya penyimpangan dalam memahami makna jïhad $\bar{f} i$ sabilillah yang sesuai dengan kaidah

${ }^{1}$ Yusuf al-Qaradhawi, Islam Ekstrem: Analisis dan Pembahasannya, terj. Alwi A.M. (Bandung: Mizan, 1989), hlm. 32. 
penafisran al-Qur'an dan hadis yang baku, sehingga menimbulkan salah paham yang disalahgunakan kaum radikalisme muslim untuk melegalkan kekerasan dalam melakukan aksinya. Penyimpangan arti jihad tersebut juga membuat kaum Orientalis memandang Islam sebagai agama yang militan yang pemeluknya dipandang sebagai serdadu-serdadu fanatik yang menyebarkan agama serta syari'atnya dengan menggunakan kekuatan senjata. ${ }^{2}$

\section{B. Pembahasan}

\section{Sekilas Tentang Epistemologi}

Epistemologi adalah salah satu cabang pokok bahasan dalam wilayah filsafat yang memperbincangkan seluk beluk pengetahuan. ${ }^{3}$ Persoalan sentral epistemologi adalah mengenai apa yang dapat kita ketahui dan bagaimana cara mengetahuinya. ${ }^{4}$ Epistemologi bermaksud mengkaji dan mencoba menemukan ciri-ciri umum dan hakikat dari pengetahuan manusia, bagaimana pengetahuan itu diperoleh dan diuji kebenarannya. ${ }^{5}$ Singkatnya, epistemologi adalah pengetahuan mengenai pengetahuan yang juga sering disebut teori pengetahuan (theory of knowledge).

Surajiyo $^{6}$ secara lebih rinci menyatakan bahwa pokok bahasan epistemologi meliputi hakikat dan sumber pengetahuan, metode memperoleh pengetahuan, dan kriteria kesahihan pengetahuan. Perlu diingat juga bahwa dalam epistemologi terdapat beberapa perbedaan mengenai teori pengetahuan, karena setiap ilmu memiliki objek, metode, sistem, dan tingkat kebenaran yang berbeda-beda, baik dari sudut pandang maupun

${ }^{2}$ Fahruroji Dahlan, "Jihad antara Fenomena Dakwah dan Kekerasan: Mereformulasi Jihad Sebagai Sarana Dakwah", dalam Jurnal al-Hikmah, Vol. I, No. I, Desember 2008 M/Zulhijah 1429 H, hlm. 71.

${ }^{3}$ Suparman Syukur, Epistemologi Islam Skolastik. (Yogyakarta: Pustaka Pelajar, 2007), hlm. 42.

${ }^{4}$ Suparlan Suhartono, Filsafat Ilmu Pengetahuan (Yogyakarta: al-Ruzz Media, 2008), hlm. 117.

5. Sudarminta, Epistimologi Dasar: Pengantar Filsafat Pengetahuan (Yogyakarta: Kanisius, 2002), hlm. 18.

${ }^{6}$ Surajiyo, Filsafat Ilmu dan Perkembangannya di Indonesia (Jakarta: Bumi Aksara, 2008), hlm. 26. 
metode. $^{7}$ Dalam wacana pemikiran Islam, secara historis para filsuf muslim telah membahas epistemologi yang diawali dengan membahas sumber-sumber pengetahuan yang berupa realitas. Realitas dalam epistemologi Islam tidak hanya terbatas pada realitas fisik, tetapi juga mengakui adanya realitas yang bersifat nonfisik, baik berupa realitas imajinal (mental) maupun realitas metafisika murni. ${ }^{8}$ Mengenai alat pencapaian pengetahuan, para pemikir Islam secara umum sepakat ada tiga alat epistemologi yang dimiliki manusia untuk mencapai pengetahuan, yaitu indra, akal, dan hati. Berdasarkan tiga alat tersebut, maka terdapat tiga metode pencapaian pengetahuan, yaitu: (a) metode observasi sebagaimana yang dikenal dalam epistemologi Barat, atau juga disebut metode bayañi yang menggunakan indra sebagai pirantinya; (b) metode deduksi logis atau demonstratif (burhāini) dengan menggunakan akal; dan (c) metode intuitif atau irfañi dengan menggunakan hati. ${ }^{9}$

Miska M. Amien ${ }^{10}$ dalam konteks ini menyatakan bahwa epistemologi Islam membahas masalah-masalah epistemologi pada umumnya dan juga secara khusus membicarakan wahyu dan ilham sebagai sumber pengetahuan dalam Islam. Wahyu hanya diberikan Allah kepada para nabi dan rasul melalui Malaikat Jibril dan berakhir pada Nabi Muhammad saw. ${ }^{11}$ Ilham adalah inspirasi atau pancaran Ilahi yang ditiupkan Ruh Suci ke dalam hati nabi atau wali. Inspirasi atau intuisi pada prinsipnya dapat diterima setiap orang. ${ }^{12}$ Oleh sebab itu, di satu sisi epistemologi Islam berpusat pada Allah, dalam arti Allah sebagai sumber pengetahuan dan kebenaran, tetapi di sisi lain, epistemologi Islam berpusat pada manusia, dalam arti manusia sebagai pelaku pencari pengetahuan (kebenaran).

${ }^{7}$ Suparlan Suhartono, Filsafat Ilmu Pengetahuan, hlm. 118.

${ }^{8}$ Mulyadi Kartanegara, Panorama Filsafat Islam (Bandung: Mizan, 2002), hlm. 58. ${ }^{9}$ Ibid., hlm. 63.

${ }^{10}$ Miska M. Amien, Epistemologi Islam (Jakarta: Universitas Indonesia, 1983), hlm. 10-11.

${ }^{11}$ Amatullah Amstrong, Khazanah Istilah Sufi: Kunci Memasuki Dunia Tasawnf, terj. Nasrullah dan Ahmad Baiquni (Bandung: Mizan, 1996), hlm. 312-313.

${ }^{12}$ Jumantoro dan Syamsul Munir, Kamus Ilmu Tasawuf (Wonosobo: Amza, 2005), hlm. 86. 


\section{Relasi Radikalisme-Fundamentalisme}

Radikalisme berasal dari kata radical yang berarti "sama sekali” atau sampai ke akar akarnya. Dalam Kamus Besar Bahasa Indonesia, radikalisme adalah paham atau aliran yang menghendaki perubahan sosial dan politik dengan cara menggunakan kekerasan sebagai batu loncatan untuk menjustifikasi keyakinan mereka yang dianggap benar. Oleh sebab itu, radikalisme bisa dipahami sebagai paham politik kenegaraan yang menghendaki adanya perubahan dan revolusi besar-besaran sebagai jalan untuk mencapai taraf kemajuan yang signifikan. ${ }^{13}$ Dengan kata lain, radikalisme adalah suatu paham sosial-politik yang dalam usaha mencapai tujuannya menggunakan cara kekerasan sehingga radikalisme yang mengatasnamakan agama merupakan sikap keras yang diperagakan oleh sekelompok penganut suatu agama dengan dalih mengamalkan ajaran agama itu.

Radikalisme dalam Islam sebenarnya sudah ada akarnya sejak zaman sahabat, yaitu ketika muncul kaum Khawarij yang tumbuh sebagai golongan radikal, baik pandangan politik maupun teologisnya, setelah memuncaknya konflik antara para pendukung Ali bin Abi Thalib r.a. dan pendukung Mu'awiyah r.a. Baik Ali maupun Mu'awiyah, menurut aliran Khawarij, telah melakukan dosa besar yang konsekwensinya dapat dihukumi kafir atau murtad, sehingga halal darahnya. ${ }^{14}$ Akhirnya sejarah mencatat bahwa Ali bin Abi Thalib ditikam oleh seorang Khawarij yang bernama Abdurrahman bin Muljam sampai wafat. Radikalisme Islam terus berkembang dengan pasang surutnya sampai dewasa ini di mana saja, termasuk di Indonesia, dan akan tetap muncul sampai kapan pun, karena memiliki akar historis dan teologis. Untuk mencegah tumbuh kembangnya radikalisme, terlebih dahulu harus dipahami apa akar yang menjadi sebab tumbuhnya radikalisme, yaitu paham atau aliran fundamentalisme.

Secara epistemologis, fundamentalisme adalah paham yang cenderung untuk memperjuangkan sesuatu secara radikal, di mana

${ }^{13}$ Dirjen Bimas Islam Kementerian Agama RI, Radikalisme Agama dan Tantangan Kebangsaan (Jakarta: Dirjen Bimas Islam Kemenag RI, 2014), hlm. 3.

${ }^{14}$ Ibid., hlm. 6. 
pelakunya adalah penganutgerakan keagamaan yang bersifat kolot dan reaksioner yang selalu ingin kembali ke ajaran agama yang asli seperti yang tersurat dalam kitab suci. Fundamentalisme Islam merupakan fenomena sosial di berbagai negara sebagai akibat dari derasnya arus modernisasi dan ketidakpuasan terhadap nilainilai sosial yang dianggap telah menyimpang dari ajaran Islam yang sesungguhnya. Aliran fundamentalisme merupakan gerakan protes politik yang diekspresikan dengan term keagamaan yang sering menggunakan tindakan radikal. Kaum fundamentalisme memiliki pandangan epistemologis bahwa Islam adalah satu-satunya jalan hidup yang harus ditegakkan tanpa harus mempertimbangkan akibatnya terhadap hak-hak kelompok atau agama lain. Pandangan kaum fundamentalisme tersebut terkesan dapat menciptakan tata sosial untuk merealisasikan kebenaran Tuhan, karena Islam menurut mereka tidak hanya sebagai agama unggulan yang terdiri atas keyakinan dan tata ibadah ansich, tetapi juga sebagai pandangan hidup dan tata budaya yang mampu dan layak menata seluruh umat manusia. ${ }^{15}$

Istilah "fundamentalis" sering dikonotasikan dengan "teroris" yang terkesan negatif dan menakutkan, karena banyak aksi-aksi kekerasan yang telah dilakukan, seperti pengeboman, penembakan, pembakaran, dan lain sebagainya. Jika disebut "teroris", orang sering menunjuk kepada gerakan Ikhwanul Muslimin di Mesir, Hizbut Tahrir di Yordania, Hamas di Palestina, Hizbullah di Libanon, Komando Jihad, Usroh, JI, MMI, dan FPI di Indonesia. Kekerasan dijadikan mereka sebagai alat ampuh untuk memenuhi keinginan beberapa individu atau kelompok fundamentalis terhadap masalah yang begitu kompleks. Tetapi secara umum, mereka memiliki orientasi untuk menjadikan Islam sebagai tatanan kenegaraan dan kebangsaan (negara Islam), karena Islam diyakini sebagai jalan keluar satu-satunya dalam mengatasi semua persoalan umat. Fenomena fundamentalisme memiliki dasar sosial-politik yang dijadikan pembenaran dari sikapnya yang radikal, keras, tak kenal kompromi, dan tak kenal toleran, antara lain sikap Barat yang tidak adil dalam berhubungan

\footnotetext{
${ }^{15}$ David Sagiv, Islam Otentisitas Liberalisme (Yogyakarta: LKiS, 1997), hlm. 4.
} 
dengan dunia Islam serta sikap Amerika dan sekutunya dalam masalah Palestina, Irak, Iran, dan lain sebagainya.

Ada beberapa faktor internal yang memicu munculnya fundamentalisme dalam Islam, yaitu:

a. Kegagalan umat Islam menghadapi arus modernisasi yang menyudutkan Islam;

b. Rasa kesetiakawanan terhadap nasib yang menimpa saudaranya di Palestina, Kashmir, Afganistan, dan Irak;

c. Dalam konteks khas Indonesia, karena kegagalan negara mewujudkan cita-cita kemerdekaan berupa tegaknya keadilan sosial dan terciptanya kesejahteraan yang merata bagi seluruh rakyat.

Secara eksternal, fundamentalisme muncul di dunia Islam disebabkan oleh beberapa faktor, antara lain imperialisme, westernisasi, Kristenisasi, sistem pemerintahan, kesenjangan ekonomi, sekularisme, liberalisme, dan terutama sikap Barat yang tidak adil dalam konflik di Timur Tengah, terutama antara Palestina dan Israel. Adapun ciri-ciri kaum fundamentalisme antara lain sebagai berikut.

a. Fundamentalisme adalah paham yang cenderung untuk memperjuangkan sesuatu secara radikal, di mana pelakunya adalah penganut gerakan keagamaan yang bersifat kolot dan reaksioner yang selalu ingin kembali ke ajaran agama yang asli seperti yang tersurat dalam kitab suci;

b. Fundamentalisme Islam merupakan fenomena sosial di barbagai negara sebagai akibat dari derasnya arus modernisasi dan ketidakpuasan terhadap nilai-nilai sosial yang dianggap telah menyimpang dari ajaran Islam yang benar;

c. Melembagakan kepemimpinan agama yang tunggal, monolitik, dan otoritatif, sehingga seorang pemimpin memiliki hak penuh untuk menentukan hitam putihnya agama;

d. Terjadinya klaim kebenaran yang berakibat timbulnya prejudice terhadap kelompok lain. 
Di samping itu, gerakan fundamentalisme dalam Islam juga memiliki karakteristik sebagai berikut. Pertama, mereka digerakkan oleh kebencian yang sangat besar kepada Barat. Kedua, mereka bersikeras untuk mengembalikan kejayaan peradaban Islam masa lalu. Ketiga, mereka bertujuan mengaplikasikan syari'at Islam dalam tatanan negara. Keempat, mereka mempropagandakan bahwa Islam itu adalah agama dan negara. Kelima, mereka menjadikan masa lalu sebagai penuntun masa depan secara revolusioner. ${ }^{16}$

Berangkat dari pemikiran di atas, dapat dipahami bahwa gerakan fundamentalisme muncul disebabkan beberapa hal, yaitu: Pertama, karena tekanan rezim politik yang berkuasa, di mana kelompok Islam tertentu tidak diberi kebebasan berpendapat. Kedua, kegagalan-kegegalan ideologi sekuler dalam menegakkan keadilan, moral, dan kesejahteraan rakyat, sehingga melahirkan radikalisme agama yang diyakini sebagai satu-satunya alternatif ideologis bagi umat Islam. Ketiga, ketidakmampuan kelompok tersebut dalam menghadapi modernitas dan perubahan sosial. Namun, tidak semua gerakan fundamentalisme mesti radikal dalam arti teroris yang sering melakukan kekerasan fisik, karena menurut Jalaluddin Rakhmat, sebenarnya ada empat model fundamentalisme Islam, yaitu:

a. Fundamentalisme sebagai gerakan tajdid, seperti yang dipelopori oleh Ibnu Taimiyah;

b. Fundamentalisme yang timbul sebagai reaksi terhadap modernisme Islam sebagai antitesa terhadap Wahabiyah dan Salafiyah yang dianggap telah mengalami distorsi historis;

c. Fundamentalisme sebagai gerakan yang menentang westernisasi di dalam Islam;

d. Fundamentalisme sebgai suatu keyakinan bahwa Islam menjadi ideologi alternatif. ${ }^{17}$

Model fundamentalisme yang pertama dan kedua kecenderungannya adalah murni perjuangan pemurnian

${ }^{16}$ Adian Husein, Rajam dalam Arus Budaya Syahwat (Jakarta: Pustaka al-Kautsar, 2001), hlm. 166.

${ }^{17}$ Muhammad Azhar, Fiqh Peradaban (Yogyakarta: Ittaga Press, 2001), hlm. 122-123. 
ajaran Islam dari berbagai tradisi lokal yang menyebabkan terkontaminasinya Islam dengan budaya masyarakat, sehingga wajah Islam tidak seperti yang pernah dicontohkan oleh Nabi Muhammad saw. Adapun fundamentalisme model ketiga dan keempat sering mengambil sikap keras dan anarkis dalam mencapai obsesinya yang dikenal dengan radikalisme. Secara umum, semua bentuk kekerasan adalah negatif, tetapi dalam kondisi darurat, kekerasan justeru diperlukan, karena jalan lain sudah tidak ditemukan. Dalam konteks dakwah Islamiyah, metode terbaik adalah pendekatan persuasif dengan konsep "ukhuwah", akan tetapi jika pihak lain bertindak sewenang-wenang, maka "kekerasan" diperlukan. Di sinilah makna "jihad" fisik yang sebenarnya, bukan sekadar instrumen untuk memenuhi keinginan beberapa individu atau kelompok fundamentalis tertentu dalam mencapai ambisi kekuasaan

\section{Epistemologi Kaum Radikal}

\section{a. Sumber Pengetahuan Kaum Radikal}

Karen Armstrong, seorang pakar pengkaji agama terkemuka di Eropa dan Amerika, membuat statemen menarik terkait dengan masalah keberagamaan umat manusia, yaitu bahwa ujian satu-satunya bagi keabsahan ide religius, pernyataan doktrinal, pengalaman spiritual, atau praktik peribadatan adalah bahwa ia harus menggiring ke arah tindakan belas kasih. Jika pemahaman Anda tentang yang Ilahi membuat Anda lebih ramah, lebih empatik, dan mendorong Anda untuk menunjukkan simpati dalam tindakan nyata, itulah teologi yang baik. Akan tetapi, jika pemahaman Anda tentang Tuhan membuat Anda tidak ramah, pemarah, kejam, atau merasa benar sendiri atau jika itu menggiring Anda membunuh atas nama Tuhan, itu adalah teologi yang buruk. ${ }^{18}$

Kaum radikal Islam dengan berbagai variannya, di dalam memperjuangkan syari'at Islam, penegakan khilafah Islamiyah, dan berbagai agenda lainnya bermuara pada satu titik, yaitu

${ }^{18}$ Zaprulkhan, Merenda Wajah Islam Humanis (Yogyakarta: Idea Sejahtera, 2014), hlm. 89. 
kembali kepada al-Qur'an dan as-Sunnah. Al-Qur'an dan asSunnah adalah satu-satunya sumber ajaran, sumber ilmu, dan sumber hukum, serta satu-satunya solusi untuk memecahkan problematika umat. Islam adalah jalan lurus (șirat. al-mustaqim) yang telah digariskan Allah di dalam al-Qur'an dan as-Sunnah yang berisi seperangkat hukum positif sebagai jalan yang benar dalam berkeyakinan, beribadah, dan bertindak dalam kehidupan sosial. Satu-satunya jalan hidup manusia di muka bumi adalah merealisasikan ajaran Allah dengan melaksanakan hukum Tuhan secara utuh dan taat.

Menurut kaum radikal, orang Islam yang mengikuti jalan hidup selain yang bersumber dari al-Qur'an dan as-Sunnah adalah kafir, munafik, dan fasik. Hal ini karena hanya ajaran yang terkandung di dalam al-Qur'an dan as-Sunnahlah yang dapat menciptakan tata sosial yang mencerminkan kebenaran Ilahi. ${ }^{19}$ Akibat dari pola pikir tersebut, mereka menyuguhkan panorama keberagamaan absolutisme, kaku, puritan, dan intoleran terhadap berbagai perbedaan pendapat keagamaan, pemahaman terhadap teks al-Qur'an dan hadis secara literal, serta mengibarkan panjipanji kebencian, permusuhan, dan kekerasan, bukan hanya kepada kalangan nonmuslim, tetapi juga kepada internal muslim yang tidak sepaham. Segala hal yang diamalkan oleh kaum radikal akan dijustifikasi, dilegitimasi dan didaulat sebagai hukum Tuhan yang bersifat mutlak, absolut, dan tidak bisa ditawar lagi. ${ }^{20}$

\section{b. Metode Memperoleh Pengetahuan}

Kehadiran radikalisme Islam yang awalnya sebagai fenomena politik ternyata mengarah pada perilaku kekerasan sistemik, kekerasan aktual, dan kekerasan simbolik. Hal ini tetaplah mengancam umat manusia, karena karakteristik gerakan mereka yang tidak mau berdialog dengan pihak lain. Mereka memaksakan pendapatnya kepada pihak lain dengan segala cara untuk bisa menerima gagasannya dan jika ada yang menolak, maka mereka tidak segan-segan memvonis kafir serta wajib diperangi

${ }^{19}$ Khalid Abou el-Fadl, Cita dan Fakta Toleransi Islam (Bandung: Mizan, 2002), hlm. 21.

${ }^{20}$ Zaprulkhan, Merenda Wajah Islam Humanis, hlm. 90. 
sampai titik darah penghabisan. ${ }^{21}$ Dari perspektif epitemologi, kaum radikal-fundamental dalam memahami ajaran al-Qur'an dan as-Sunnah, menurut Yusuf al-Qaradhawi, memiliki metode sebagai berikut.

1. Kecenderungan zahiri dalam memahami nash-nash (secara harfiah);

2. Sibuk mempertentangkan hal-hal sampingan seraya melupakan probelm-problem pokok;

3. Berlebih-lebihan dalam mengharamkan segala sesuatu;

4. Pemahaman keliru dalam beberapa pengertian;

5. Kedangkalan pikiran dalam memahami Islam dan ketidakjelasan pandangan tentang pokok syari'atnya. ${ }^{22}$

Implikasi dari model penafsiran dan pola pikir epistemologi di atas, maka mereka mencukupkan diri dengan interpretasi keagamaan yang didasarkan pada pemahaman literal dan tekstual, sehingga pemahaman mereka terhadap substansi ajaran Islam menjadi lemah. Sebab, mereka tidak mempelajari berbagai penafsiran yang ada, kaidah-kaidah ushul fiqh, ataupun pendekatan pemahaman teks yang lazim digunakan para ulama. ${ }^{23}$ Menurut Malik Fadjar, pola keberagamaan kaum radikal juga mengakibatkan beberapa hal sebagai berikut.

1. Memahami agama lebih mengutamakan teks secara literal dan skriptural dengan menafikan segala bentuk penafsiran kontekstual, karena dikhawatirkan akan mereduksi absolutisme dan universalitas kebenaran agama;

2. Agar pemahaman tersebut diakui otoritasnya, maka mereka melembagakan kepemimpinan agama yang tunggal, monolitik, dan otoritatif, sehingga seorang pemimpin memiliki hak penuh untuk menentukan hitam-putihnya agama;

${ }^{21}$ Zuly Qodir, Radikalisme Agama di Indonesia (Yogyakarta: Pustaka Pelajar, 2014), hlm. 41.

${ }^{22}$ Yusuf al-Qaradhawi, al-Hạal wa al-Hăàm fi al-Is Tam (Dār al-Baiḍā': Dār alMa'rifah, 1985), hlm. 67.

${ }^{23}$ Ahmad Rodli, Stigma Islam Radikal (Yogyakarta: Pustaka Pelajar, 2013), hlm. 75. 
3. Konsekwensinya adalah terjadinya klaim kebenaran yang berakibat timbulnya prejudice terhadap kelompok lain. ${ }^{24}$

Menarik sekali dalam memabahas kelompok ini adalah hasil penelitian Saad Eddin Ibrahim mengenai profilnya, yaitu bahwa rata-rata mereka adalah muda, berasal dari kelas menengah, mempunyai motivasi prestasi yang tinggi, bergerak ke atas (mobilitas vertikal), berpendidikan sains atau teknik, dan berasal dari keluarga yang kohesif. Kebanyakan mereka tidak bersifat marginal, anomis, atau abnormal, bahkan mereka dianggap sebagai model anak muda Mesiar. ${ }^{25}$ Fenomena komunitas kaum fundamental-radikal tersebut memang menarik, tetapi lebih menarik lagi jika mencermati karakteristik keberagamaan mereka sebagaimana dikemukakan Yusuf al-Qaradhawi sebagai berikut.

1. Fanatik kepada suatu pendapat dan tidak mengakui pendapat-pendapat lain;

2. Mewajibkan atas manusia sesuatu yang tidak diwajibkan oleh Allah atas mereka, yakni mewajibkan hal-hal yang sebenarnya sunnah dan mangharamkan hal-hal yang sebenarnya makruh;

3. Memperberat suatu ajaran Islam yang tidak pada tempatnya, seperti mempersoalkan duduk di atas kursi ketika menghadiri majelis taklim, bukan duduk di atas tikar atau sajadah sebagaimana di masjid, tidak menghadap kiblat sebagaimana adab seorang muslim, mengenakan celana bukan jubah putih, makan di atas meja bukan di atas lantai, dan lain sebaginya;

4. Sikap kasar dan keras dalam berkomunikasi dan berdakwah, yang hal ini bertentangan secara petunjuk Allah swt. dan praktik Rasulullah saw. yang justru berperangai halus dan lemah lembut;

5. Buruk sangka terhadap manusia atau orang lain serta memandang mereka dengan kaca mata hitam, dengan menyembunyikan kebaikan-kebaikan mereka dan membesar-besarkan keburukannya;

${ }^{24}$ Malik Fadjar, Merambah Jalan Baru dalam Beragama (Yogyakarta: Ittaqa Press, 2000), hlm. ix.

${ }^{25}$ Prisma, Nomor Extra, 1984, hlm. 85. 
6. Terjerumus ke dalam jurang pengafiran terhadap kelompok lain. ${ }^{26}$

Mengomentari model epistemologi kaum fundamentalradikal di atas, cendekiawan muslim Indonesia terkemuka, Nurcholish Madjid, menyatakan bahwa hal tersebut disebabkan mereka kurang menghargai terhadap warisan Islam klasik, sehingga mengalami kemiskinan intelektual dan alternatifalternatif pemikirannya sangat terbatas yang berakibat miskin konsep-konsep intelektual dan tidak bakal mampu menopang tuntutan zaman yang semakin maju. ${ }^{27}$

Model epistemologi yang demikian jelas-jelas sangat berpotensi menimbulkan konflik yang destruktif dalam kehidupan sosial, karena dalam beragama tidak cukup hanya terpaku pada satu aspek tekstual atau kultus kepada seorang pemimpin, tetapi harus melihat aspek-aspek lain secara komprehensif. Model epistemologi keberagamaan yang parsial seperti itu akan membawa akan sikap eksklusif dalam interaksi sosial, yang tentunya sangat berpotensi konflik. Perlu diingat bahwa dalam pandangan Islam, sikap menghargai dan toleran kepada pemeluk agama lain adalah mutlak, sebagai bagian dari keberagamaan inklusif, meskipun anggapan bahwa semua agama sama (pluralisme) tidak dibenarkan.

Sikap inklusif terhadap pemikiran yang lain akan menimbulkan rasa saling menghormati dan menghargai dalam bentuk yang disebut pluralisme pemikiran dan pemahaman. Sudah saatnya pemuka-pemuka berbagai agama di dunia duduk bersama dalam suatu forum diskusi di mana mereka dapat saling berdialog untuk saling mendewasakan pemikiran serta pemahaman masing-masing. Lebih lanjut diharapkan setelah berdiskusi dapat mengalami proses konversi dari pemahaman agama yang sempit (eksklusif) menjadi terbuka (inklusif) dalam tataran pluralisme pemikiran serta pemahaman, sehingga pada akhirnya umat manusia dapat bahu-membahu untuk menciptakan kemaslahatan umum.

${ }^{26}$ Yusuf al-Qaradhawi, al-Halal wa al-Haram, hlm. 32-46.

${ }^{27}$ Muhammad Azhar, Fiqh Peradaban, hlm. 122-123. 


\section{c. Validitas Kebenaran}

Dimensi epistemologi yang penting lainnya adalah masalah kriteria kebenaran pengetahuan yang menjadi tolok ukur suatu konsep suatu pengetahuan. Kaum fundamental-radikal dalam paradigma epistemologi memiliki ukuran-ukuran tertentu dalam menilai suatu pandangan keagamaan yang dipasung oleh teks secara literal, skriptural, dan eksklusif. Mereka menolak berbagai bentuk telaah kritis terhadap teks al-Qur'an dan hadis dengan berbagai macam interpretasinya, terutama penafsiran teks dengan model hermeneutika. Menurut mereka, teks al-Qur'an harus dipahami secara literal, sebagaimana adanya. Demikian pula mereka menolak interpretasi teks agama dengan perspektif historis dan sosiologis yang dianggap telah membawa manusia semakin jauh dari doktrin literal kitab suci. Dalam konteks ini, mereka berprinsip bahwa masyarakatlah yang harus menyesuaikan perkembangannya dengan teks kitab suci, bukan sebaliknya. Oleh sebab itu, dapat disimpulkan bahwa kaum fundamental-radikal ini di dalam menilai kebenaran suatu konsep keberagamaan bersifat ahistoris dan asosiologis, dengan tujuan kembali pada bentuk masyarakat ideal seperti zaman salaf yang dipandang sebagai pengejawantahan kitab suci secara sempurna. ${ }^{28}$

Doktrin syari'ah bagi mereka adalah baku dan sakral sebagai satu-satunya hukum tunggal sebagaimana diterapkan pada abadabad umat Islam, dan kemuudian syari'at berubah menjadi dasar ideologis semua aspek kehidupan sosial. Dengan demikian, validitas kebenaran pengetahuan diukur dengan formalisasi pelembagaan fatwa syari'ah yang diideologisasi menjadi doktrin perubahan sosial dan hubungan dengan negara yang berakar dari hubungan dialek elite-umat yang membentuk klientalisme syari'ah. ${ }^{29}$ Pandangan mengenai keharusan penerapan syari'ah di semua lapangan kehidupan yang dipegang teguh kaum radikalisme adalah syari'at yang bersumber dari referensi doktrinal ulama

${ }^{28}$ Martin E. Marty, dalam Hasan Basri, "Fundamentalisme Islam dalam Pandangan Sayyid Qutb", dalam Jurnal Empirisme, STAIN Kediri, Volume 9, Nomor 2, Juli-Desember 2002, hlm. 52-53.

${ }^{29}$ Fazlur Rahman, Islam (Bandung: Pustaka, 1984), hlm. 33. 
salaf. Ini jelas tampak pada semua gerakan, baik yang tradisional, modernis, maupun neo-modernis.

Epistemologi kaum fundamentalisme-radikalisme Islam ini, jika ditilik dari paradigama epistemologi Islam yang digagas oleh Abid al-Jabiri, termasuk epistemologi bayañi. Bayañi adalah model epistemologi yang menekankan otoritas teks (nash) secara langsung atau tidak langsung, dan dijustifikasi lewat nalar kebahasaan yang digali lewat inferensi (istidlal) secara langsung ataupun tidak langsung. Secara langsung, artinya memahami teks sebagai pengetahuan yang sudah jadi, langsung diaplikasikan tanpa pemikiran. Secara tidak langsung, artinya memahami teks sebagai suatu pengetahuan mentah sehingga perlu ditafsirkan dengan penalaran. Meskipun demikian, peran akal atau rasio tidaklah bebas. Sebab, dalam tradisi bayañi, rasio atau akal tidak mampu memberikan pengetahuan kecuali disandarkan pada teks. ${ }^{30}$ Epistemologi bayañi akan menghasilkan al-îlm at-tauqiji. Pokok bahasan al-ilm at-tauqifi adalah teks atau nash yang berisi wahyu Allah swt., yakni bahasan tentang agama, bukan tentang keberagamaan. ${ }^{31}$

Kelemahan epistemologi dengan tradisi berpikir tekstual (baya-ini) adalah ketika dia harus berhadapan dengan teks keagamaan yang membicarakan komunitas, kultur, bangsa, atau masyarakat yang beragama lain menimbulkan permasalahan tersendiri. Ada kecenderungan ketika berhadapan dengan agama lain cenderung defensif, apologis, dan pesimistis. Upaya untuk menghindari hal itu semua, dan termasuk untuk pengembangan pola pikir bayāini ini, jika pengayom pola pikir ini mampu memahami, berdialog, dan mengambil manfaat sisi fundamental yang dimiliki oleh pola pikir lain, yaitu 'irfäini dan pola pikir burbañi. Begitu pula sebaliknya, sebab ketiga pola pikir ini merupakan pola pikir yang serumpun. Bayāini sangat berkaitan erat dengan realitas, maka persoalan pokok (tool of analysis) yang ada di dalamnya adalah

${ }^{30}$ Abid al-Jabiri, Bunyah al-'Aql al-'Arabi (Beirut: Markāz aś-Saqafí al- 'Arabī, 1999), hlm. 17.

${ }^{31}$ Muslim A. Kadir, Ilmu Islam Terapan (Yogyakarta: Pustaka Pelajar, 2003), hlm. 26. 


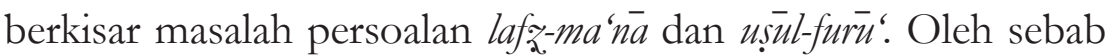
itu, untuk mendapatkan pengetahuan dari teks, epistemologi bayāini menempuh dua jalan. Pertama, berpegang pada redaksi (laf $:$ ) teks, dengan menggunakan kaidah bahasa Arab, seperti Nahwu dan Sharaf sebagai alat analisis. Kedua, berpegang pada makna teks dengan menggunakan logika, penalaran, atau rasio sebagai analisis. ${ }^{32}$

Sementara, epistemologi irfäini digunakan untuk membedakan antara pengetahuan yang diperoleh dengan indra dan akal dengan pengetahuan yang diperoleh melalaui kasyf (ketersingkapan). Epistemologi irfänisecara umum menggunakan metode penghayatan batin dengan beberapa istilah yang khas bagi kaum sufi. Adapun epistemologi burbañi atau pendekatan rasional argumentatif adalah pendekatan yang didasarkan pada kekuatan rasio yang dilakukan melalui dalil-dalil logika. Teks dan konteks dalam pendekatan ini, "sebagai dua sumber kajian", berada dalam satu wilayah yang saling berkaitan. Teks tidak berdiri sendiri, ia selalu terkait dengan konteks yang mengelilingi dan mengadakannya sekaligus konteks dari mana teks itu dibaca dan ditafsirkan, sehingga pemahaman burhäini akan lebih kuat.

Menurut Amin Abdullah, tolok ukur validitas keilmuannya pun sangat berbeda dari nalar bayāini dan nalar 'irfäini. Jika nalar bayāini tergantung pada kedekatan dan keserupaan teks atau nash dan realitas, dan nalar irfäini lebih pada kematangan social skill (empati, simpati, verstehen), maka dalam nalar burhäini yang ditekankan adalah korespondensi (al-mutabaqab baina al-'aql wa nizăm at-tabi'ab), yakni kesesuaian antara rumus-rumus yang diciptakan oleh akal manusia dengan hukum-hukum alam. Selain korespondensi juga ditekankan aspek koherensi (keruntutan dan keteraturan berpikir logis) dan upaya yang terus-menerus dilakukan untuk memperbaiki dan menyempurnakan temuantemuan, rumus-rumus, dan teori-teori yang telah dibangun dan disusun oleh jerih payah akal manusia (pragmatik). Kalau saja

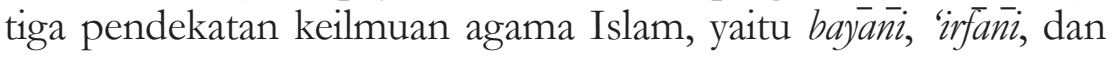
burháni saling terkait, terjaring, dan terpatri dalam satu kesatuan

${ }^{32}$ Abid al-Jabiri, Bunyah al-'Aql al-'Arabi, hlm. 530. 
yang utuh, maka corak dan model keberagamaan Islam, menurut hemat penulis, jauh lebih komprehensif, dan bukannya bercorak dikotomis-atomistis seperti yang dijumpai sekarang ini. ${ }^{33}$

\section{Simpulan}

Berangkat dari pembahasan di atas, dapat penulis rangkum intisari atau kesimpulan sebagai berikut.

1. Ekstremitas kaum fundamentalisme secara internal disebabkan oleh beberapa faktor, antara lain kecenderungan memahami nash secara literal, perhatian yang berlebihan pada masalah furüiyah, minimnya wawasan tentang hakikat Islam, dan lemahnya wacana keilmuan sejarah dalam kehidupan sosial.

2. Kaum radikalisme Islam dengan berbagai variannya, di dalam memperjuangkan syari'at Islam, penegakan khilafah Islamiyah, dan berbagai agenda lainnya, semuanya bermuara pada satu titik, yaitu kembali kepada al-Qur'an dan as-Sunnah. Al-Qur'an dan asSunnah adalah satu-satunya sumber ajaran, sumber ilmu, dan sumber hukum, serta satu-satunya solusi untuk memecahkan problematika umat.

3. Metode yang digunakan dalam memahami agama lebih mengutamakan teks secara literal dan skriptural dengan menafikan segala bentuk penafsiran kontekstual, karena dikhawatirkan akan mereduksi absolutisme dan universalitas kebenaran agama.

4. Menurut mereka, validitas kebenaran terletak pada teks suci yang dipahami secara literal, sebagaimana adanya. Oleh sebab itu, mereka menolak interpretasi teks agama dengan perspektif historis dan sosiologis yang dianggap telah membawa manusia semakin jauh dari doktrin literal kitab suci. Dalam konteks ini, mereka berprinsip bahwa masyarakatlah yang harus menyesuaikan perkembangannya dengan teks kitab suci, bukan sebaliknya.

${ }^{33}$ Amin Abdullah, Islamic Studies di Perguruan Tinggi (Yogyakarta: LKiS, 2006), hlm. 386. 
Fathul Mufid

\section{DAFTAR PUSTAKA}

Abdullah, Amin, Islamic Studies di Perguruan Tinggi, Yogyakarta: LKiS, 2006.

Amien, Miska M., Epistemologi Islam, Jakarta: Universitas Indonesia, 1983.

Amstrong, Amatullah, Khazanah Istilah Sufi: Kunci Memasuki Dunia Tasawnf, terj. Nasrullah dan Ahmad Baiquni, Bandung: Mizan, 1996.

Azhar, Muhammad, Figh Peradaban, Yogyakarta: Ittaga Press, 2001.

Basri, Hasan, "Fundamentalisme Islam dalam Pandangan Sayyid Qutb", dalam Jurnal Empirisme, STAIN Kediri, Volume 9, Nomor 2, Juli-Desember 2002.

Dahlan, Fahruroji, "Jihad antara Fenomena Dakwah dan Kekerasan: Mereformulasi Jihad Sebagai Sarana Dakwah", dalam Jurnal al-Hikmah, Vol. I, No. I, Desember 2008 M/Zulhijah 1429 H.

Dirjen Bimas Islam Kementerian Agama RI, Radikalisme Agama dan Tantangan Kebangsaan, Jakarta: Dirjen Bimas Islam Kemenag RI, 2014.

Fadjar, Malik, Merambah Jalan Baru dalam Beragama, Yogyakarta: Ittaqa Press, 2000.

el-Fadl, Khalid Abou, Cita dan Fakta Toleransi Islam, Bandung: Mizan, 2002.

Husein, Adian, Rajam dalam Arus Budaya Syahwat, Jakarta: Pustaka al-Kautsar, 2001.

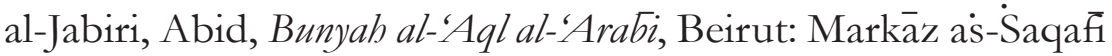
al- 'Arabi, 1999.

Jumantoro dan Syamsul Munir, Kamus Ilmu Tasawuf, Wonosobo: Amza, 2005.

Kadir, Muslim A., Ilmu Islam Terapan, Yogyakarta: Pustaka Pelajar, 2003.

Kartanegara, Mulyadi, Panorama Filsafat Islam, Bandung: Mizan, 2002. 
al-Qaradhawi, Yusuf, al-Halal wa al-Haram fí al-Istam, Dār alBaidāa': Dār al-Ma'rifah, 1985. , Islam Ekstrem: Analis dan Pembahasannya, terj. Alwi A.M., Bandung: Mizan, 1989.

Qodir, Zuly, Radikalisme Agama di Indonesia, Yogyakarta: Pustaka Pelajar, 2014.

Rahman, Fazlur, Islam, Bandung: Pustaka, 1984.

Rodli, Ahmad, Stigma Islam Radikal, Yogyakarta: Pustaka Pelajar, 2013.

Sagiv, David, Islam Otentisitas Liberalisme, Yogyakarta: LKiS, 1997.

Sudarminta, J., Epistimologi Dasar: Pengantar Filsafat Pengetahuan, Yogyakarta: Kanisius, 2002.

Suhartono, Suparlan, Filsafat Ilmu Pengetahuan, Yogyakarta: alRuzz Media, 2008.

Surajiyo, Filsafat Ilmu dan Perkembangannya di Indonesia, Jakarta: Bumi Aksara, 2008.

Syukur, Suparman, Epistemologi Islam Skolastik, Yogyakarta: Pustaka Pelajar, 2007.

Zaprulkhan, Merenda Wajah Islam Humanis, Yogyakarta: Idea Sejahtera, 2014. 
Fathul Mufid

Halaman ini tidak sengaja untuk dikosongkan 